\title{
급속 OUR 모니터링을 이용한 Microbial Respiration (MR) 영향인자 평가 Factors Affecting Microbial Respiration (MR) by Rapid Oxygen Uptake Rate (OUR) Monitoring
}

\author{
박세용·모 경·김연권* 김문일 ${ }^{\dagger}$ \\ Seyong Park $\cdot$ Kyung Mo $\cdot$ Youn-Kwon Kim* ${ }^{*}$ Moonil Kim ${ }^{\dagger}$ \\ 한양대학교 건설환경공학과 - *한국수자원공사 수자원연구원 \\ Department of Civil and Environmental Engineering, Hanyang University \\ *K-water Institute, $K$-water
}

(2011년 2월 10일 접수, 2011년 9월 28일 채택)

\begin{abstract}
As this study was estimation of factors of rapid OUR (Oxygen Uptake Rate) monitoring method. Experiment for estimating factors of optimal microorganism activity was carried out in this study. In addition to comparison and estimation of SCOD variation by OUR variation using real wastewaters. In consequence OUR value was highest when $\mathrm{F} / \mathrm{M}$ ratio, $\mathrm{pH}$ and temperature were $0.03 \sim 0.05,6.0 \sim 8.5$ and $20 \sim 30^{\circ} \mathrm{C}$ respectively. Oxygen consumption by nitrification was incomplete. OUR variation of SCOD was recognizable difference of degradable rate at before and after of inflection point OUR. This study used an experimental method for real time prediction of the influent of the sewage treatment plant for optimal operation is expected to be able to do. Key Words : Rapid OUR (Oxygen Uptake Rate), Optimal Microorganism Activity, Factors
\end{abstract}

요약 : 본 연구는 급속 OUR (Oxygen Uptake Rate)방법의 영향인자 평가로서 최적의 미생물 활성도에 미치는 영향인자를 평 가하는 실험을 진행하였으며, 실폐수를 이용하여 OUR변화에 따른 SCOD의 변화를 비교 평가하였다. 그 결과 최적의 $\mathrm{F} / \mathrm{M}$ 비는 $0.03 \sim 0.05$ 이었고, $\mathrm{pH}$ 는 $6.0 \sim 8.5$, 온도는 $20 \sim 30^{\circ} \mathrm{C}$ 에서 $\mathrm{OUR}$ 값이 가장 높았으며, 질산화에 대한 산소소모는 미비했다. OUR 변화에 따른 SCOD (Soluble COD)의 변화는 OUR 변곡점 시간 전후로 SCOD의 분해속도에 차이가 있음을 알 수 있었 다. 본 연구의 실험방법을 이용하여 하수처리장의 유입수 실시간 예측을 통해 최적의 운영을 할 수 있을 것이라 기대한다. 주제어 : 급속 OUR (Oxygen Uptake Rate), 미생물 활성도, 영향인자

\section{1. 서 론}

하수처리장의 운전/관리 최적화를 위해서는 현재 유입되 고 있는 유입수 특성 파악이 중요하며, 그 중에서도 유입 $\mathrm{COD}$ 에 대한 정확하고도 신속한 사전인지여부는 하수처리 장 운영모델 모사에 있어 매우 중요한 인자로서 최근에는 이러한 모니터링 기법과 실증규모 하수처리장의 적용-성 공 사례가 발표되고 있다. ${ }^{1)}$

하수처리장 운영모델 모사에서 가장 중요한 점은 신속하 고도 정확하며 기존 이화학적 분석으로는 확인이 불가능한 $\mathrm{COD}$ 의 분석능 확보인데, Spanjers 등레 의하면 미생물을 이용한 산소 이용률(OUR; Oxygen Uptake Rate) 측정방법 은 하수처리의 각 공정을 모니터링하고 미생물의 동역학적 인자 도출을 가능하게 할 수 있다고 제시하였다. 또한 OUR 은 이화학적 분석이 불가능한 이분해성 $\mathrm{COD}(\mathrm{RBCOD}$; Readily Biodegradable COD)의 분율분석에 매우 유용한 방법 으로 알려져 있다. ${ }^{3)}$ 이는 미생물의 호흡과 성장, 그리고 유 기물, 질소 제거기작에 산소가 직접적으로 관여하고 있기 때문으로, ${ }^{4)}$ 하수처리 공정을 해석하고 하수처리 모델의 구 성인자를 도출하는데 매우 유용한 방법으로 활용되기 시작 하였다. ${ }^{5,6)}$ 일반적으로 유입수내 $\mathrm{RBCOD}$ 를 측정하기 위한
OUR 실험은 높은 $\mathrm{F} / \mathrm{M}$ 비(>1 mg COD/mg VSS) 조건에서 장 시간 동안 기질 제거와 산소소모량, 그리고 미생물량의 변 화를 통해 그 결과를 획득하였다. 하지만, 이는 미생물 성 장을 고려하여야 하기 때문에 보다 복잡한 동역학적 해석 이 필요하다. ${ }^{78)}$ 반면, 낮은 $\mathrm{F} / \mathrm{M}$ 비 $(<0.2 \mathrm{mg} \mathrm{COD} / \mathrm{mg} \mathrm{VSS})$ 에 서는 기질제한으로 인해, 오염물질이 급속히 분해되고 특 별한 biomass 성장이 발생하지 않기 때문에 단기간에 실험 결과를 도출할 수 있어 ${ }^{7,8)}$ 하수 처리장 운영의 실시간 공정 제어가 가능할 것이라 판단된다.

급속 OUR 방법으로 $\mathrm{RBCOD}$ 의 정확한 예측값을 위해서는 미생물의 활성도(Yield)가 최적화 되어야 하며, 미생물의 활 성도에 영향을 주는 인자(F/M비, 온도, $\mathrm{pH}$, 질산화 등)를 평 가 하여 최적의 값을 도출해야 한다.

따라서 본 연구에서는 합성폐수를 이용한 급속 OUR 곡 선의 변화추이를 확인할 수 있는 최적 $\mathrm{F} / \mathrm{M}$ 비를 도출하였고, 미생물 호흡율 변화특성에 영향을 미치는 인자(온도, $\mathrm{pH}$, 질산화)들에 대하여 검토하였다. 또한 $\mathrm{A}$ 시 하수처리장으로 유입되는 실폐수를 이용하여 OUR의 변화에 따른 $\mathrm{SCOD}$ (Soluble COD)의 변화를 비교하였다. 본 연구를 통해 하수 처리장으로 유입되는 실폐수를 실시간으로 예측하여 최적 의 하수처리장 운영을 할 수 있을 것이라 기대한다. 


\section{2. 재료 및 방법}

\section{1. 실험 장치}

호흡도 분석을 위하여 제작된 회분식 반응기는 Fig. 1과 같다. 두께 $0.5 \mathrm{~cm}$ 의 아크릴재질의 원통형 포기부와 $\mathrm{DO}$ 측 정부, $\mathrm{DO}$ meter로 구성되어 있다. 포기부와 $\mathrm{DO}$ 측정부는 펌프를 통해 60 초 간격으로 $\mathrm{ON} / \mathrm{OFF}$ 를 통해 순환되며 $\mathrm{DO}$ meter (YSI 5100)를 이용하여 DO 변화를 측정하였다. 연속 적인 $\mathrm{DO}$ 변화를 측정하기 위해 $\mathrm{DO}$ 측정부 반응기는 2 개 로 설치하였고 자석 교반기에 의해 $700 \pm 10 \mathrm{rpm}$ 으로 교반시 켰으며 공기의 유출 - 입을 막기 위해 DO Probe와 반응기 사이를 O-ring으로 밀폐시켰다.

\section{2. 실험 방법}

본 연구에서 사용된 슬러지는 A시 하수처리장의 생활하수 반송슬러지(MLSS $5500 \pm 100 \mathrm{mg} / \mathrm{L}$, MLVSS $5000 \pm 100 \mathrm{mg} / \mathrm{L}$ ) 를 채취하여 24시간 폭기시켜 내생호흡단계에 이르게 하여 사용하였다. 합성폐수 조제는 Glucose를 사용하였는데, 김철 ${ }^{9}$ 의 실험결과에 의하면 Glucose의 경우 Bacto-peptone, Starch 에 비해 DO 농도 변화가 매우 큰 폭으로 감소함을 알 수 있었다. 이는 일반적으로 알려진 바와 같이 Glucose가 미생 물에 의해 쉽게 분해되기 때문이다. 실폐수는 $\mathrm{A}$ 시 하수처 리장의 생활하수 및 공장계폐수를 사용하였는데, 생활하수 의 경우 다른 하수처리장과 성상의 차이는 거의 없었다. 공 장계폐수의 경우 종류 및 제조 물질에 따라 성상의 차이가 있을 수 있다. 하지만, $\mathrm{A}$ 시의 경우 대단위 공업단지를 보유 하고 있는 도시로서 각종 공장 폐수가 집수되어 유입되기 때문에 다른 도시의 하수처리장으로 유입되는 공장 폐수를 대표할 수 있다고 판단된다.

실험방법은 먼저 합성폐수의 $\mathrm{DO}$ 측정 전 슬러지의 내생 호흡율(Endogenous)을 파악하기 위해 슬러지와 수돗물을 1:1 로 섞어 폐수와 동일한 1 분 간격으로 $\mathrm{DO}$ 를 측정하였다. 내
생 호흡율 측정 후 반응기에 24시간 동안 소화시킨 슬러지 와 시료(합성폐수)를 주입한 후, 1 분 정도 교반시켜 충분히 혼합이 되도록 하였다. 이후 DO 변화를 측정하여 내생호흡 율까지 OUR이 감소하였을 때를 반응이 끝났다고 판단하였 다. OUR은 반응시간에 대한 산소의 소모량 $\left(\mathrm{mg} \mathrm{O}_{2} / \mathrm{L} \cdot \mathrm{hr}\right)$ 으 로 계산하였다. 모든 실험에서 $\mathrm{pH}$ 와 온도는 각각 $7.0 \pm 0.5$, $21 \pm 2{ }^{\circ} \mathrm{C}$ 를 유지하였다. ${ }^{9}$

\section{3. 분석방법}

모든 분석은 Standard Methods ${ }^{10)}$ 에 준하여 $\mathrm{DO}, \mathrm{pH}$, 온도, $\mathrm{CODcr}, \mathrm{SS}, \mathrm{VSS}$ 를 분석하였다. $\mathrm{COD}$ 의 분석을 위해 시료 는 3 분 간격으로 반응기로부터 $10 \mathrm{~mL}$ 씩 채취하였다. 이때 반응기의 상부를 하양 압밀함으로써 반응기내에 공기층의 형성을 억제하여 용존 산소 농도의 변화를 방지하였다. SCOD 분석을 위해 $\mathrm{GF} / \mathrm{C}$ filter paper (Whatman International Ltd., England)로 고액 분리하여 측정하였다.

\section{3. 결과 및 고찰}

\subsection{OUR 변화 추이에 따른 최적 $\mathrm{F} / \mathrm{M}$ 비 도출}

급속 OUR 방법의 적합성을 평가하고 실폐수의 실험 전 최적의 $\mathrm{F} / \mathrm{M}$ 비를 평가하기 위한 실험을 진행하였다. $\mathrm{F} / \mathrm{M}$ 비 는 0.0045 를 시작으로 점차 증가시키면서 Microbial Respiration (MR) 반응 변화와 반응 종료시간을 보았다. $\mathrm{F} / \mathrm{M}$ 비가 작을수록 OUR의 변곡점은 짧은 시간 내에 떨어지고, 클수 록 변곡점은 긴 시간에 걸쳐 떨어지게 된다. 이것은 먹을 수 있는 기질이 많을수록 미생물이 긴 시간동안 기질을 소 모하며 호흡을 하고, 기질이 적을수록 짧은 시간에 소모하 며 호흡을 하기 때문이다. 본 연구에서는 적정 OUR 변곡점 시간을 15 20분으로 결정하였다. 하수처리장 운영 모델에 서 중요한 점은 $\mathrm{RBCOD}$ 값을 정확하고 빠르게 예측할 수

Fig. 1. Schematic diagram of OUR tester.

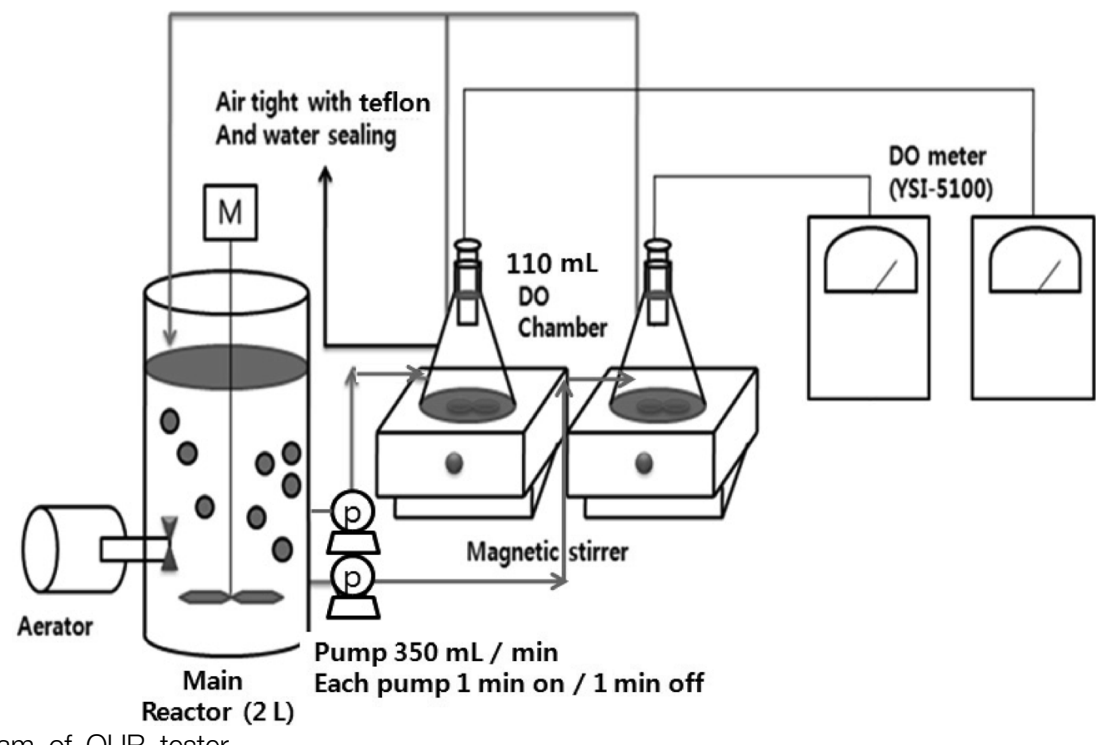


있는 능력이다. RBCOD는 쉽게 분해가 가능한 유기물로서 분해 시간이 짧기 때문에 단시간 내에 값을 판단 할 수 있 어야 한다. 이에 따라 본 연구는 최적의 시간이라 판단되는 $15 ~ 20$ 분을 적용하여 평가하였다. Glucose를 이용한 합성폐수 실험 결과 Fig. 2와 같이 F/M비 0.0390, 0.04431, 0.05381일 때 OUR은 약 15 18분 사이에서 급격히 떨어지는 것을 확 인 할 수 있다. 각 실험은 $\mathrm{F} / \mathrm{M}$ 비 값에 따라 10 회의 반복실 험을 하였다.

앞서 언급한 바와 같이 $\mathrm{F} / \mathrm{M}$ 비가 커질수록 OUR 값이 감 소되는 시간도 길어짐을 알 수 있다. 일반적인 활성 슬러지 공법의 경우 $\mathrm{F} / \mathrm{M}$ 비는 $0.10 \sim 0.35$ 가 사용되며 생물학적 처리를 위한 적정 $\mathrm{F} / \mathrm{M}$ 비는 미생물종에 따라 차이가 있기는 하지만 일반적으로 $0.4 \sim 1.0^{11,12)}$ 으로 제시되고 있다. 본 연구에서의 실험결과, 제시된 최적의 시간(실험시간)에서 합성폐수의 성 상을 예측할 수 있는 F/M비는 0.03 0.05로 나타났다.

합성폐수와 실폐수는 성상적인 측면에서 차이가 있다. 따라서 실폐수의 적용 $\mathrm{F} / \mathrm{M}$ 비와 합성폐수에 적용된 $\mathrm{F} / \mathrm{M}$ 비 는 다른 값의 결과가 도출될 수 있다. 하지만, 실폐수의 MR 반응 종료 시간을 $15 \sim 20$ 분에 맞추는 $\mathrm{F} / \mathrm{M}$ 비를 예상하기는

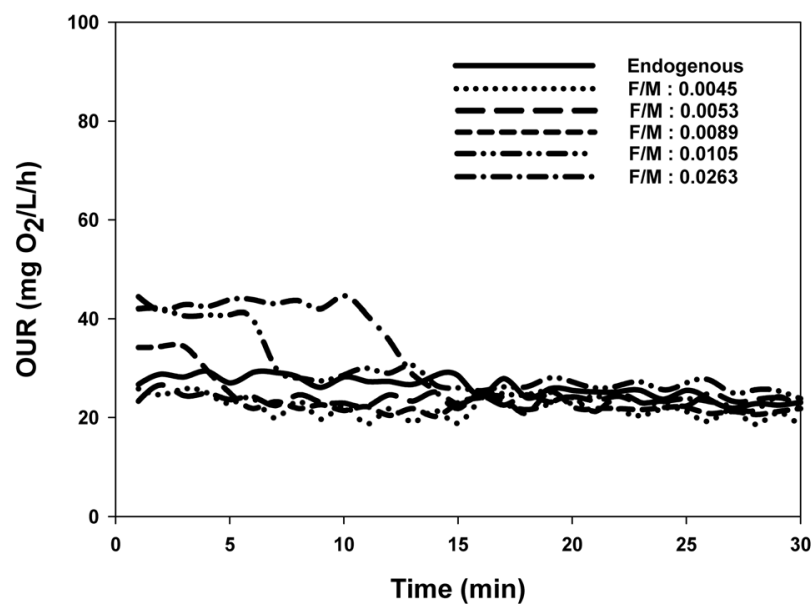

(a) F/M : 0.0045 0.0263, Standard deviation (0.091 7.83), $\mathrm{n}=10$

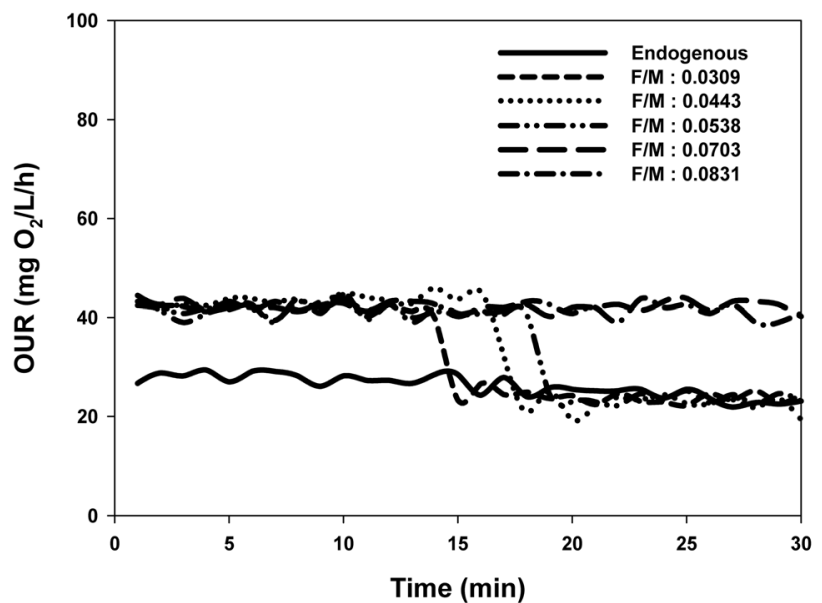

(b) F/M : 0.0309 0.0831, Standard deviation (0.346 11.803), $\mathrm{n}=10$

Fig. 2. Optimal F/M ratio according to both OUR and reaction time with synthetic wastewater.

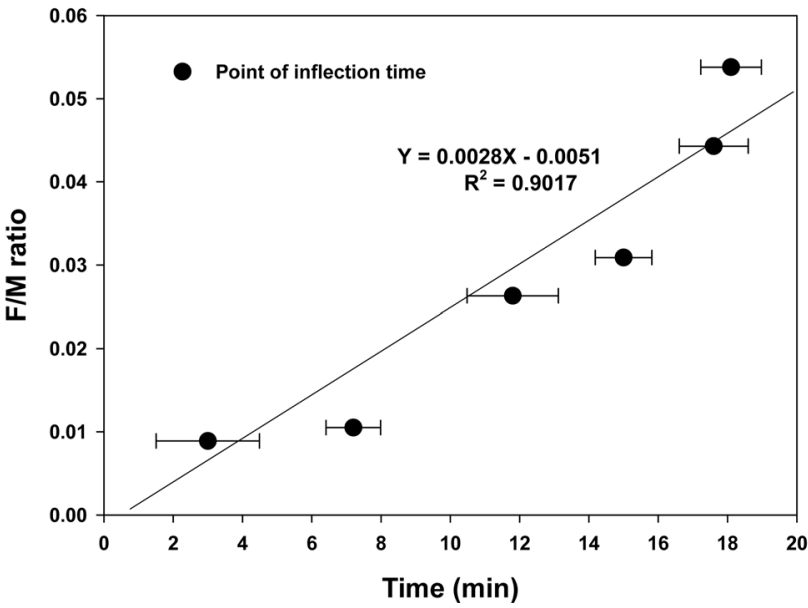

Fig. 3. F/M ratio according to point of inflection time (Standard deviation : 0.78 1.49, $\mathrm{n}=10$ ).

어렵다. 따라서 실폐수의 MR 반응 종료 시간을 적정의 시 간에 맞추기 위해서 먼저 합성폐수로서 도출된 0.03 0.05 의 중간값인 0.04 를 적용하여 실험한 후, 적절하지 않을 경 우 OUR 변화 그래프를 통해 예측이 가능한 F/M비를 적용 하여 실험을 진행해야 할 것으로 판단된다.

합성 폐수를 각 $\mathrm{F} / \mathrm{M}$ 비에 따라 10 회씩 반복하여 도출된 변곡점 시간을 Fig. 3에 나타내었다. $x$ 축은 변곡점 시간을 나타내며, $\mathrm{y}$ 축은 $\mathrm{F} / \mathrm{M}$ 비를 나타낸다. $\mathrm{F} / \mathrm{M}$ 비 증가에 따라 변 곡점 시간이 길어지는 것을 알 수 있다. 본 실험을 통해 얻 어진 결과 값의 신뢰도는 $90 \%$ 였으며, 추세선을 통해 얻어 진 식으로 1 시간 뒤 변곡점이 발생하는 $\mathrm{F} / \mathrm{M}$ 비를 예측하였 을 때 0.167 로 예측할 수 있었다.

\section{2. 최적조건을 위한 $\mathrm{pH}$, 온도 조절 및 Allylthiourea- (ATU) 주입 실험}

OUR에 영향을 주는 요소는 F/M비 이외에도 미생물의 동 력학적 계수 값과 다양한 환경요소가 있다. 그 중에서 특히 $\mathrm{pH}$, 온도 그리고 독성물질이 OUR 값에 크게 영향을 주는 인자로 알려져 있다. ${ }^{13,14)}$ 본 연구에서는 $\mathrm{pH}$, 온도, 그리고 질산화 영향을 확인하기 위해 각각의 조건을 변화시켜가며 OUR 특성을 비교평가 하였다. 특히, 급속 OUR 실험에서 독립영양 미생물에 의한 영향정도를 평가하기 위해 질산화 방지제인 $\mathrm{ATU}$ 를 주입하여 그 결과를 비교하였다. 영향인자 실험을 위해 내생호흡율 측정방법과 동일한 방법으로 OUR 을 측정하였으며, 사용된 sample은 Endogenous 상태인 슬 러지와 수돗물을 $1: 1$ 로 섞어 실험을 하였고, 3 5회 반복 실험을 하였다. Fig. 4 6 내에 반복된 실험은 "Run"으로 표 현하였다.

일반적으로 하수처리장 유입수내 $\mathrm{pH}$ 는 하수처리공정 내 미생물에 큰 영향을 준다. 하수처리 공정의 미생물은 $\mathrm{pH}$ 변 화에 민감하여 강산 또는 강알칼리 상태일 경우 미생물의 활성도를 저하시키고, 심하면 미생물의 세포벽과 조직을 파 괴하여 하-폐수 처리기능을 파괴하기도 한다. ${ }^{15)}$ 또한 $\mathrm{pH}$ 
가 강산이거나 강알칼리일 때 독성물질과 유사한 특성을 나타내게 되며 이는 급격한 OUR 변화로서 알 수 있다.

Fig. 4에서 보는바와 같이, $\mathrm{pH}$ 6.0 8.5에서 미생물의 활성 도가 가장 높은 것으로 나타났으며, $\mathrm{pH} 5.0$ 이하 또는 $\mathrm{pH}$ 9.0 이상의 구간에서는 미생물의 활성도가 $1 / 2$ 이상 감소하 는 것으로 나타났다. 즉, 다양한 $\mathrm{pH}$ 범위에서 나타나는 동 일 미생물의 OUR 값은 강산성과 강알칼리 영역으로 갈수 록 내생호흡 상태의 OUR 값보다 급격히 감소함을 확인할 수 있었는데, 이 구간에서는 미생물이 $\mathrm{pH}$ 영향에 의해서 미 생물이 사멸되기 때문이다. 이는 강산과 강알칼리 구간에 서 $\mathrm{pH}$ 변화에 의한 저해(Inhibition)와 세포벽 파괴 등의 현 상이 복합적으로 나타나고 있기 때문으로 사료된다. ${ }^{15)}$ 본 실험결과 적정 $\mathrm{pH}$ 범위는 6.0 8.5로 나타났으며, 이 결과 는 김 등 $^{15)}$ 이 연구한 결과와도 유사한 것으로 판단되었다. 하지만 추후 독성물질 주입에 따른 미생물의 활성도를 직 접적으로 평가하는 것이 필요하다고 판단된다. 비록 본 연 구에서는 $\mathrm{pH}$ 의 평가를 통해 독성물질 유입 시 OUR 변화를 간접적으로 평가할 수 있었지만, 직접적인 평가를 통해 미생 물 거동이나, 특성 변화를 평가해 볼 필요가 있다.

Fig. 5는 다양한 온도 조건에서의 OUR 변화를 나타낸 그 래프이다. 온도 변화에 따른 미생물의 활성도를 측정하기 위해 먼저 내생호흡 상태일 때 온도와 OUR을 측정하였다.

측정결과 정상적인 온도 약 $20 ~ 300^{\circ} \mathrm{C}$ 일 때, sample의 OUR 값이 가장 높았다. 온도가 약 $20^{\circ} \mathrm{C}$ 이하로 떨어지거나 약 30 ${ }^{\circ} \mathrm{C}$ 이상으로 상승하였을 때, Sample의 OUR 값은 내생호흡 상태의 값보다 $1 / 2$ 이상 감소하는 결과가 나타났다. 이는 앞 서 $\mathrm{pH}$ 실험과 동일한 이유로서 온도의 급격한 감소와 증가 로 인해 미생물의 활성도를 저하시키기 때문으로 판단된다. 일반적으로 온도에 따른 미생물 성장속도는 온도가 $10^{\circ} \mathrm{C}$ 와 $20^{\circ} \mathrm{C}$ 에서 약 2 배 정도의 성장 속도 차이를 보인다. 본 실험에서 $15^{\circ} \mathrm{C}$ 와 $30^{\circ} \mathrm{C}$ 에서 각각 OUR 값이 $13,25 \mathrm{mg} \mathrm{O} /$ $\mathrm{L} / \mathrm{h}$ 로서 앞서 제시한 미생물 성장속도와 거의 일치한 값이 나왔음을 알 수 있다. 이것은 OUR이 미생물의 활성도 측 정용으로도 활용이 가능하지만 미생물의 성장지표로도 활

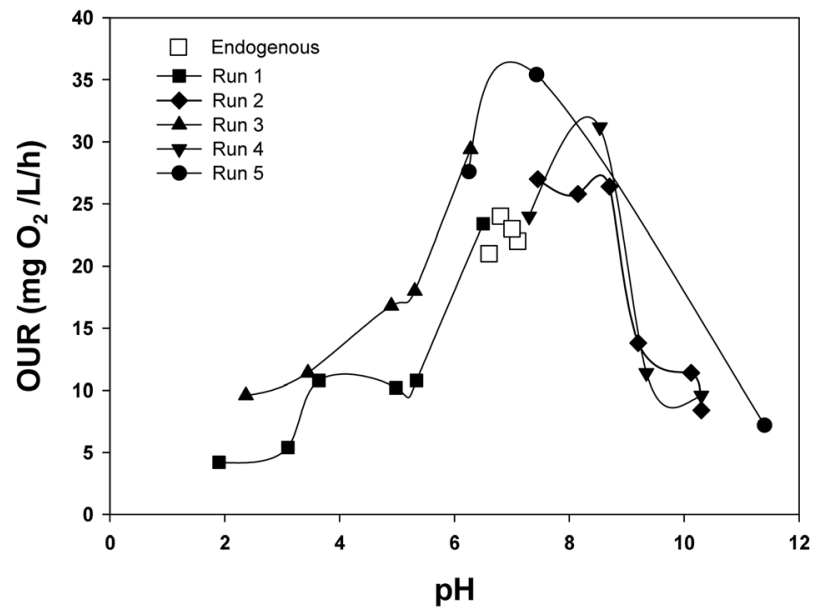

Fig. 4. Optimal pH for OUR.

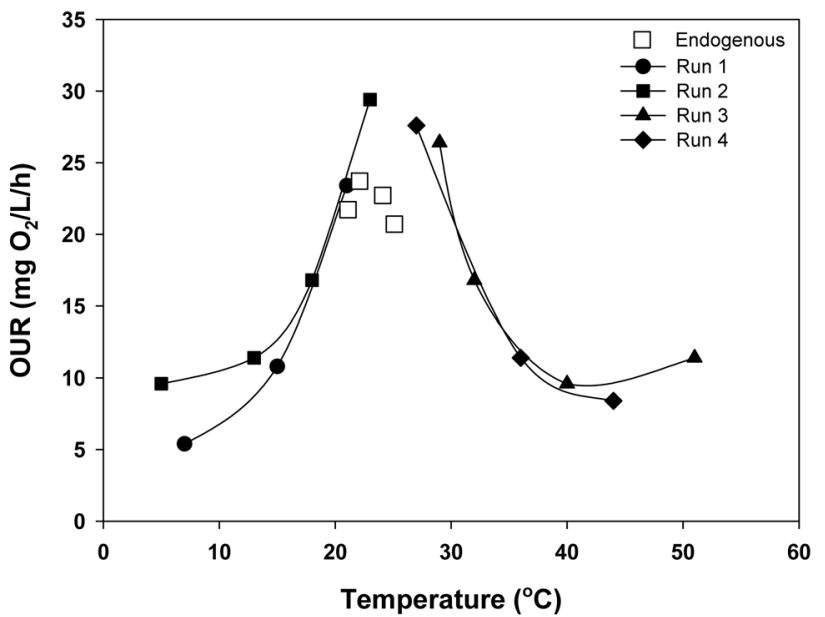

Fig. 5. Optimal temperature for OUR.

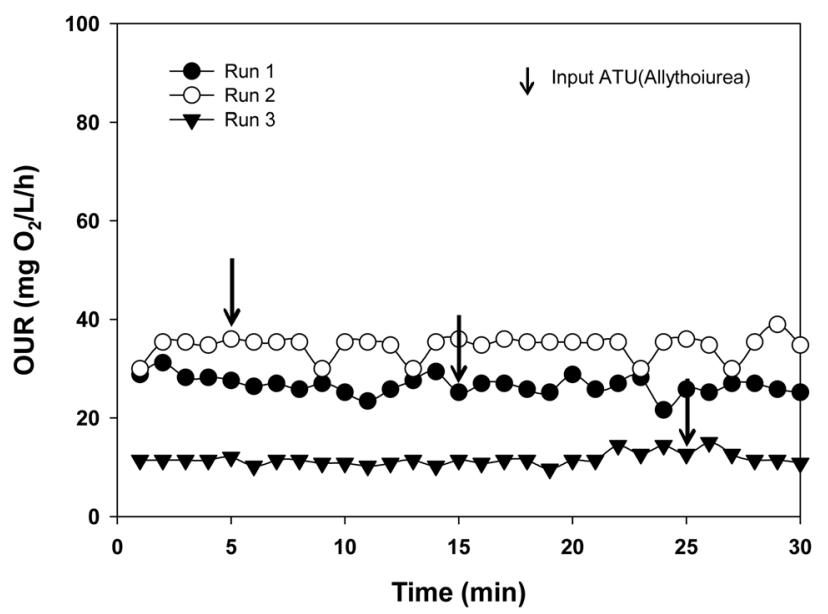

Fig. 6. Influence of ATU on OUR response.

용이 가능하다는 것을 나타낸다. 따라서 본 실험결과로 미 루어 미생물의 최적 활성에 미치는 온도범위는 $20^{\circ} \mathrm{C}$ 부터 약 $30^{\circ} \mathrm{C}$ 이고, 이때 가장 활발히 활동하고 성장하는 것으로 판단되었다.

$\mathrm{pH}$, 온도 두 실험을 통해 급속 미생물 호흡율 측정(OUR) 모니터링 방법은 하수처리장 공정 내 미생물의 활성도를 실시간으로 측정할 수 있는 방법으로 활용될 수 있을 것으 로 판단된다.

Fig. 6은 질산화 영향을 알아보기 위한 실험으로 질산화 방 지 억제제인 ATU (1-Allyl-2-thiourea, Aldrich Chemical Company, Inc.) 주입에 따른 OUR 반응을 나타낸 것이다. ATU 의 양은 기존의 문헌을 참고하여 $20 \mathrm{mg} / \mathrm{L}$ 로 주입하였다. ${ }^{16}$ 질산화가 일어나면 독립영양 미생물의 산소소모로 인해 OUR 값은 크게 증가할 것이다. 하지만 그림에서 확인 할 수 있듯이, 실험간 ATU 주입에 따른 OUR 값의 감소는 매 우 미미한 것으로 나타났다. 이는 질산화에서 암모니아성 질소 및 질산염을 기질로 이용하는 질산화균은 독립영양 미 생물 군으로 유기물의 분해로부터 성장하는 종속영양 미생 물군보다 성장속도가 상대적으로 매우 느리기 때문이다. 따 라서 본 실험의 경우 30 분 동안의 짧은 반응시간으로 유기 
물을 분해하는 미생물이 암모니아성 질소 및 질산염을 기질 로 하는 질산화균의 성장 속도보다 빠르기 때문에 질산화 에 의한 산소소모는 없거나 거의 무시할 만한 것으로 판단 되었다.

\subsection{OUR 변화에 따른 SCOD 변화}

Fig. 7은 A시 하수처리장으로 유입되는 생활하수와 공장 계 폐수의 OUR 곡선에 따른 SCOD 변화를 나타낸 그래프 이다. 그래프에서 알 수 있듯이 생활하수와 공장계 폐수 모 두 시간이 지날수록 미생물의 유기물 분해로 인해 SCOD 값은 감소하고 있는 것을 알 수 있다. $\mathrm{F} / \mathrm{M}$ 비는 앞서 3.1절 의 합성폐수의 실험을 토대로 생활하수와 공장계 폐수의 다양한 $\mathrm{F} / \mathrm{M}$ 비 실험을 통해 20 분대에서 변곡점이 발생하는 $\mathrm{F} / \mathrm{M}$ 비를 파악하였으며, 결과 생활하수는 0.04 , 공장계폐수 는 0.0075 로 도출되었다.

Fig. 7(a)는 생활하수의 OUR 곡선에 따른 SCOD를 나타 낸 것이다. 결과 OUR 변곡점이 발생하는 20 분대를 기준으
로 $\mathrm{SCOD}$ 의 제거되는 속도를 비교했을 때, 0 20분까지의 제거 속도가 20 분 후의 제거 속도보다 빠르다는 것을 알 수 있다. 이는 최초 미생물의 성장과 호흡을 통해 약 20 분 까 지 빠르게 기질을 소모하면서 SCOD의 제거속도가 빠르게 이루어졌고, 약 20 분후는 기질 소비를 모두 하여 미생물이 내생호흡 단계에 이르면서 제거속도가 느리게 이루어졌다 고 판단된다.

Fig. 7(b)는 공장계 폐수의 OUR 곡선에 따른 SCOD 값을 나타낸 것으로 생활하수와 다르게 OUR 변곡점이 7분, 18 분대에서 2 회 발생을 하였다. 본 실험의 경우 짧은 시간에 미생물이 유기물을 분해하는 실험으로서 미생물의 호흡과 성장에 사용된 유기물은 쉽게 분해 될 수 있는 RBCOD로 판단할 수 있다. 시료는 공장계 폐수로서 각종 산업체에서 사용되는 폐수가 혼합된 것으로 최초 7 분까지는 메탄올과 에탄올 등 $\mathrm{RBCOD}$ 중에서도 더 쉽게 분해가 될 수 있는 물질이라고 판단된다. ${ }^{17)}$ 유기물 분해 역시 7 분대까지의 분 해속도가 가장 빠른 것을 볼 수 있으며 반응 후 18 분 후

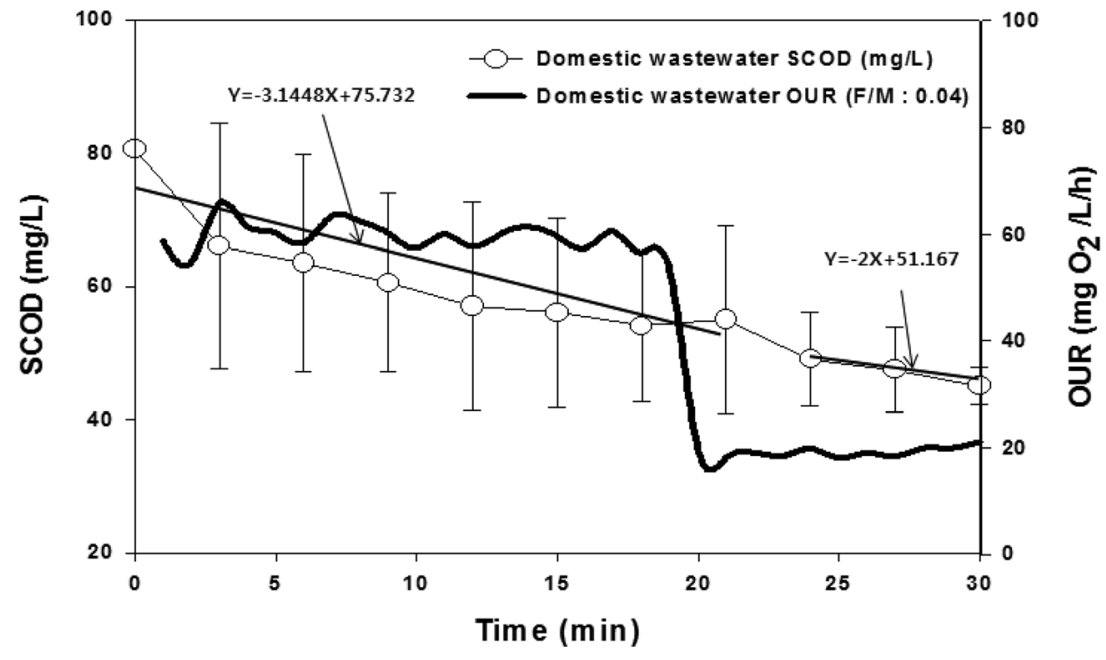

(a) Domestic wastewater SCOD and OUR (F/M : 0.0400)

OUR Standard deviation (0.42 13.57, $n=10)$, SCOD $(n=5)$

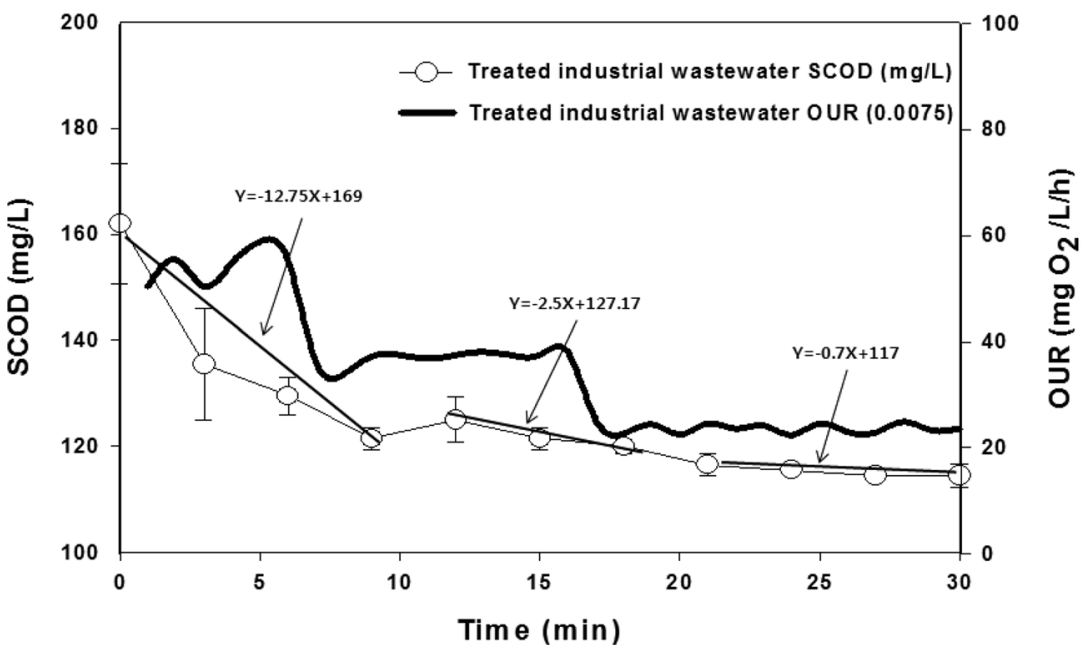

(b) Treated industrial wastewater SCOD and OUR (F/M : 0.0075)

OUR Standard deviation (0.30 7.63, $n=10)$, SCOD $(n=5)$

Fig. 7. OUR curves of treated industrial wastewater compared with SCOD and OUR. 
부터는 내생호흡단계로서 $\mathrm{RBCOD}$ 의 분해가 가장 느린 것 을 볼 수 있다. MR 반응시간이 30 분 이후 실험을 더 진행 할 경우 변곡점이 다시 발생할 것으로 판단이 되는데, 이때 소모되는 $\mathrm{COD}$ 는 $\mathrm{SBCOD}$ (Slowly Biodegradable COD)라 사료된다.

\section{4. 결 론}

본 연구는 급속 OUR 측정방법과 장치를 이용하여 최적의 $\mathrm{F} / \mathrm{M}$ 비를 도출했으며, OUR 변화에 미치는 영향인자를 평가 하였고, 실폐수를 이용한 OUR 변화와 SCOD 변화를 비교 검토하여 다음과 같은 결론을 얻었다.

1) A시 하수처리장 생활하수 반송슬러지(MLVSS, 5,000 $\mathrm{mg} / \mathrm{L})$ 와 합성폐수(Glucose)로 $\mathrm{pH} 7$, 온도 $25^{\circ} \mathrm{C}$ 일 때, 적정 $\mathrm{F} / \mathrm{M}$ 비 실험 결과 $0.03 \sim 0.05$ 로 나타났다.

2) OUR 영향인자 평가를 위한 $\mathrm{pH}$, 온도, 질산화 실험 결 과 $\mathrm{pH}$ 는 $6.0 \sim 8.5$, 온도는 $20 \sim 30^{\circ} \mathrm{C}$ 에서 가장 활발한 미생물 활성도를 보였으며, 질산화에 대한 영향은 미비하거나 없 는 것으로 판단되었다.

3) A시 하수처리장에 유입되는 생활하수, 공장계폐수를 대상으로 $\mathrm{OUR}$ 과 $\mathrm{SCOD}$ 의 변화패턴을 비교한 결과, OUR 변곡점 발생 전까지의 $\mathrm{SCOD}$ 의 분해속도가 변곡점 후의 분 해속도 보다 빠른 것을 알 수 있었다. 이는 본 실험의 급속 OUR 실험 시 빠른 시간 내에 실험이 종료된다. 따라서 유기 물 중에서 쉽게 분해 할 수 있는 유기물을 분해하면서 미생 물의 호흡과 성장을 한다는 것을 알 수 있었다.

4) 본 연구는 기존의 OUR 방법을 개선하고자 한 연구로 서 급속 OUR 방법과 기존의 OUR 방법의 영향인자를 비 교 검토한 연구로서 기존의 연구방법에서 도출된 영향인자 들이 본 연구에서 제시하는 급속 OUR 방법에도 동일하게 적용이 된다는 것을 확인할 수 있었다.

\section{사 사}

본 연구는 한국수자원공사의 연구비 지원으로 수행되었으 며 이에 깊은 감사를 드립니다.

KSEE

\section{참고문헌}

1. 한국수자원공사, "자가진단형 하수처리장 운영관리시스템 (상용화버전)의 개발 및 실규모 하수처리장 현장적용 연구 (2차년도)," K-water 연구원(2009).
2. Spanjers, H., Takeks, I. and Brouwer, H., "Direct parameter extraction form respirograms for wastewater and biomass characterization", Water. Sci. Technol., 39(4), 137 145(1999).

3. Vanrolleghem, P. A., van Daele, M. and Dochin, D., "Preactical identifiability of a bioinetic model of activated sludge respiration," Water. Res. 29(11), 2561 2570(1997).

4. Sperandio Mathieu and Paul Etienne, "Estimation of wastewater biodegradable COD fraction by combing respirometric experiments in variors $\mathrm{SO} / \mathrm{XO}$ ratios," Waste. Res., 34(4), 1233 1246(2000).

5. Cheryl, M. Kussow, Weichang Zhou, David, M. Gryte and Wei-Shou Hu, "Monitoring of mammalian cell growth and virus production process using on-line oxygen uptake rate measurement," Enzyme Microb. Technol., 17, 779 783(1995).

6. 정형석, “호흡률 측정법을 이용한 생물학적 질소 제거공정 의 모니터링과 시뮬레이션," 한국과학기술원 석사학위 논문, pp. 1 5(2000).

7. Chudoba, P., Capdeville, B. and Chudoba, J., "Explanation of biological meaning of the So/Xo ratio in batch cultivation," Water. Sci. Technol., 26, 743 751(1992).

8. Wentzel, M. C., Mbewe, A. and Ekama G. A., "Batch test for measurment of readily biodegradable COD and active organism concentration in municipal wastewaters," Water SA., 21 (2), 117 124(1995).

9. 김 철, “호흡도 기법을 통한 폐수내 $\mathrm{COD}$ 분율 예측," 한양 대학교 석사학위 논문, pp. 28 33(2000).

10. "Standard methods for the examination of water and wastewater," APHA, AWWA, WEF, 21th edition, Washington, D. C (2005).

11. 성낙창 외, “폐수의 활성슬러지 처리,” 신광문화사, p. 341 (2000).

12. Bruce, E. Rittmann, Perry, L. McCarty, "Environmental Biotechnology: Principles and Applications," Mcgraw-Hill, 324 326(2001)

13. Henze, M., Gujer W., Mino, T. and van Loosdrecht M. C. M., "Activated sludge models ASM 1, ASM 2, ASM 2d, and ASM 3," IWA Scientific and Tech Report., No. 9(2000).

14. Chung, J. W., "Factors affecting nitroe accumulation and process optimization in a shortcut biological nitrogen removal hybrid reactor", ph. D. thesis. Hanyang University, Department of Civil and Environmental Engineering, Korea, pp. 225 231(2001).

15. 김연권, 문용택, 김지연, 서인석, " $\mathrm{pH}$ 조절을 통한 폐활성 슬러지의 $\mathrm{COD}$ 가용화 및 감량화 평가," 상하수도학회지, 21(5), 551 558(2007).

16. Orhon, D. and Çokgör, E. U., "COD fractionation wastewater characterization-The state of the art," J. Chem. Technol. Biotechnol, 68, 283 293(1997).

17. Kim, Y. K., "Respirometric monitoring of microbial behavioral characteristics change through the retrofitting process," $\mathrm{Ph}$. D. Thesis. Hanyang University, Department of Civil and Environmental Engineering, Korea, pp. 210 214(2003). 